\title{
Importance of Von Kleihauer Betke Test Assay in Estimating Fetomaternal Hemorrhage
}

\author{
Dr. Jeevaraj Giridharan*, Dr. Pramila R, Dr. Sarada V \\ Department of Pathology, Trichy SRM Medical College Hospital \& Research Centre, Trichy, 621105, Tamil Nadu, India
}

DOI: 1 10.36348/sjpm.2020.v05i08.004 $\quad$ | Received: 04.08.2020 | Accepted: 12.08 .2020 | Published: 16.08 .2020

*Corresponding author: Dr. Jeevaraj Giridharan

\section{Abstract}

Objectives: Fetomaternal hemorrhage (FMH) refers to the passage of fetal blood into the maternal circulation before or during delivery. Besides the deleterious effects of anemia in the fetus, allo sensitization of the mother to red cell particularly Rh antigens may result in significant mortality/morbidity in the current fetus or in future gestations. $\mathrm{HbF}$ resist acid-elution to a greater extent than do normal cells and it can be detected by Kleihauer Betke method. The objective is to study the importance of Von Kleihauer Betke test and its application in identifying the red cells containing fetal hemoglobin $(\mathrm{HbF})$ and to calculate its percentage of existence in mothers during labor, at Trichy SRM Medical College Hospital \& Research Centre. Materials and Methods: To study the importance of Von Kleihauer Betke test and its application in assessing fetomaternal haemorrhage, intravenous blood samples were collected from all the mothers, who got admitted for labor at Trichy SRM Medical College Hospital \& Research Centre during July 2017 - Sep 2017. Thin blood smears were prepared and stained by acid elusion method. The stained slides were examined for red cells containing $\mathrm{HbF}$ fewer than $100 \mathrm{x}$ oil immersion microscope by the investigators separately to reduce subjective variation. To calculate the number of red blood cells containing HbF in mother, Von Kleihauer Betke test formula has been used. Blood grouping test of the entire mother and their neonates also was done to identify the Rh typing. Von Kleihauer Betke test has been implicated to calculate the dosage of RhIG to be given in Rh negative mothers with Rh positive babies. Observation and result: Among 215 mothers involved in the study, $\mathrm{HbF} \%$ range was observed to be within $0-2.0 \%$. No significant percentage of fetomaternal haemorrhage exceeding $2 \%$ was observed in our study during the study period. Among the samples of 215 mothers studied, $\mathrm{HbF}$ range was lowest $(0-0.5 \%)$ in $40 \%(\mathrm{n}=88)$, mid-range $(0.6-1.5 \%)$ in $42 \%(\mathrm{n}=89)$ and higher range $(1.6-2 \%)$ in $17 \%(\mathrm{n}=38)$ only.

Keywords: Fetal haemoglobin, Fetomaternal haemorrhage, Von Kleihauer Betke test.

Copyright @ 2020: This is an open-access article distributed under the terms of the Creative Commons Attribution license which permits unrestricted use, distribution, and reproduction in any medium for non-commercial use (NonCommercial, or CC-BY-NC) provided the original author and sources are credited.

\section{INTRODUCTION}

Fetomaternal hemorrhage (FMH) is the passage of fetal blood into the maternal circulation. It can be passed before labor or during delivery. Allo sensitization of the mother to red blood cells particularly $\mathrm{Rh}$ antigens may result in significant mortality/morbidity in the existing fetus or in concurrent pregnancy. Another major indication for the testing of maternal blood for the presence of fetal red cells is to assess placental injury following acute trauma in a pregnant woman $[1,2]$. As FMH may be asymptomatic in the mother, the diagnosis requires a high index of clinical suspicion. It can be augmented by laboratory testing for the presence of fetal red cells in maternal blood. Fetal red cells quantitation in maternal blood by Von Kleihauer Betke test is used to estimate the size of fetomaternal haemorrhage. It can also implied to calculate the dose of RhIG needed to prevent
$\mathrm{Rh}$-sensitization in a woman who is $\mathrm{Rh}$ negative and delivers an Rh-positive baby [3,4].

The Von Kleihauer Betke test is an acidelution cytochemical method used to quantitate fetomaternal haemorrhage [5-7]. It identifies red blood cells containing hemoglobin $\mathrm{F}$ since they resist acidelution to a greater extent than normal red blood cells. Other indications of Von Kleihauer Betke test were implied when there is persistence of hemoglobin $\mathrm{F}$ is suspected such as in hereditary persistence of hemoglobin F, sickle cell anemia, acquired aplastic anemia, thalassemia, and other hemoglobinopathies [8, 9].

\section{MATERIALS AND METHODS}

Setting: Department of Pathology, Trichy SRM Medical College Hospital and Research Centre, Trichy. 
Duration: July 2017 to Sep 2017.

Type of study: Cross sectional study

Sampling Size calculation: Based on previous studies and statistical formula, sample size was determined with alpha error of 0.05 and power of 0.95

Sample size: 215

\section{Inclusion Criteria}

All pregnant women who got admitted for institutional delivery at Trichy SRM Medical College Hospital and Research Centre from July 2017 to Sep 2017

\section{Exclusion Criteria}

Pregnant women who were in other trimesters and not in labor at Trichy SRM Medical College Hospital and Research Centre during the study period
Data collection procedure: The blood smears from all the mothers sample were made and stained by acid elusion method of Von Kleihauer betke. The fetal red cells were observed under microscope by the investigators to reduce the subjective variation and the percentage of fetal hemoglobin was calculated.

Data analysis: Categorical variables were expressed in percentages, pie chart and bar diagram. Student $\mathrm{T}$ test was applied for calculating statistical significance when data followed nominal distribution. Mann whitney test applied when data followed non nominal distribution. Nominal categorical data between the groups was compared using Chi-square test or fisher's exact test as appropriate. $\mathrm{P}<0.05$ was taken to indicate a statistical significant difference.

Ethical permission: Obtained

\section{OBSERVATION AND RESULT}

Table-1: Percentage of Fetal Red Blood cells calculated in 215 mothers during the study period by Von Kleihauer Betke test

\begin{tabular}{|c|c|c|}
\hline Fetal red cells \% & No. of Mothers & $\%$ \\
\hline 0.0 & 35 & 16.3 \\
\hline 0.1 & 21 & 9.7 \\
\hline 0.2 & 8 & 3.7 \\
\hline 0.3 & 9 & 4.2 \\
\hline 0.4 & 7 & 3.2 \\
\hline 0.5 & 8 & 3.7 \\
\hline 0.6 & 11 & 5.6 \\
\hline 0.7 & 7 & 3.2 \\
\hline 0.8 & 8 & 3.7 \\
\hline 0.9 & 2 & 0.9 \\
\hline 1.0 & 13 & 6.0 \\
\hline 1.1 & 9 & 4.2 \\
\hline 1.2 & 16 & 7.4 \\
\hline 1.3 & 3 & 1.4 \\
\hline 1.4 & 5 & 2.3 \\
\hline 1.5 & 15 & 7.0 \\
\hline 1.6 & 10 & 4.6 \\
\hline 1.7 & 9 & 4.2 \\
\hline 1.8 & 4 & 1.8 \\
\hline 1.9 & 5 & 2.3 \\
\hline 2.0 & 10 & 4.6 \\
\hline Total & 215 & $100 \%$ \\
\hline
\end{tabular}




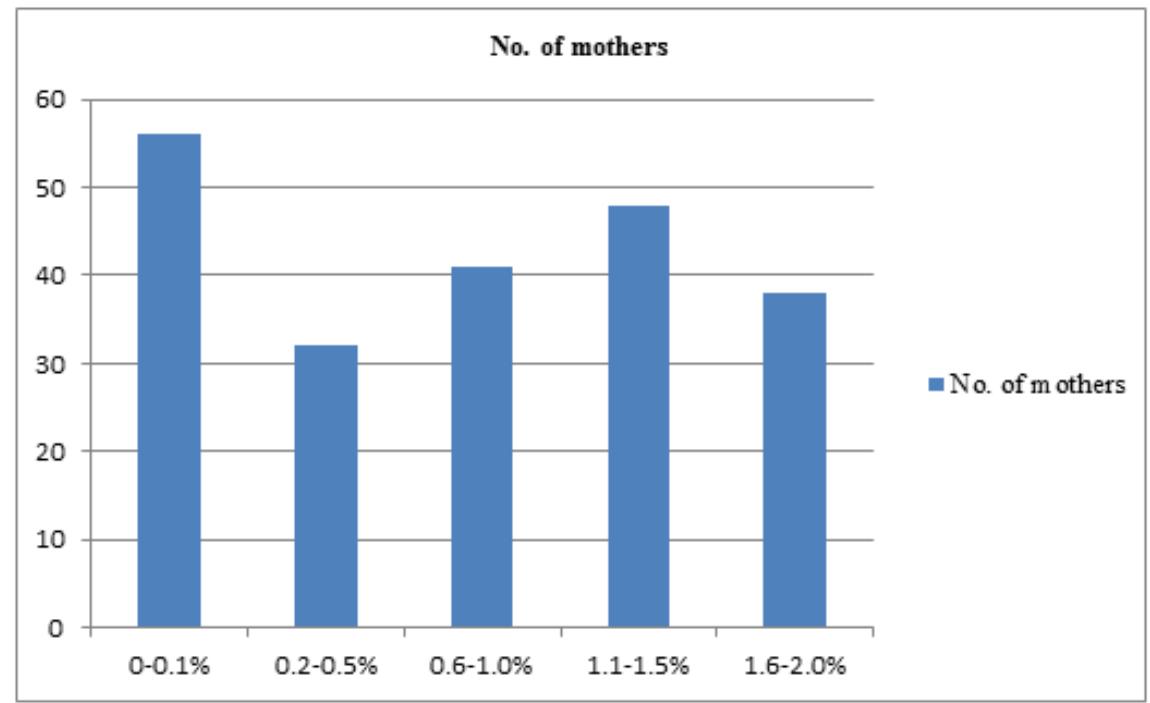

Fig-1: Percentage of HbF distribution in 215 mothers during the study period

In our study, 215 mothers were assessed for fetomaternal hemorrhage by Von Kleihauer Betke test. Among that, 56 mothers $(26.0 \%)$ have found to be completely devoid of fetal red cells $0.0 \%-0.1 \%$. 32 mothers $(14.8 \%)$ with $0.2 \%-0.5 \%$ fetal red cells. 41 mothers $(19.3 \%)$ with $0.6 \%-1.0 \%$ of fetal red cells,
48 mothers $(22.3 \%)$ with $1.1 \%-1.5 \%$ of fetal red cells, 38 mothers $(17.6 \%)$ with of fetal red cells range of $1.6 \%-2.0 \%$ [Table-1, Fig-1,2]. No significant percentage of feto maternal hemorrhage exceeding $2 \%$ (as per other laboratory references) been observed in our study.

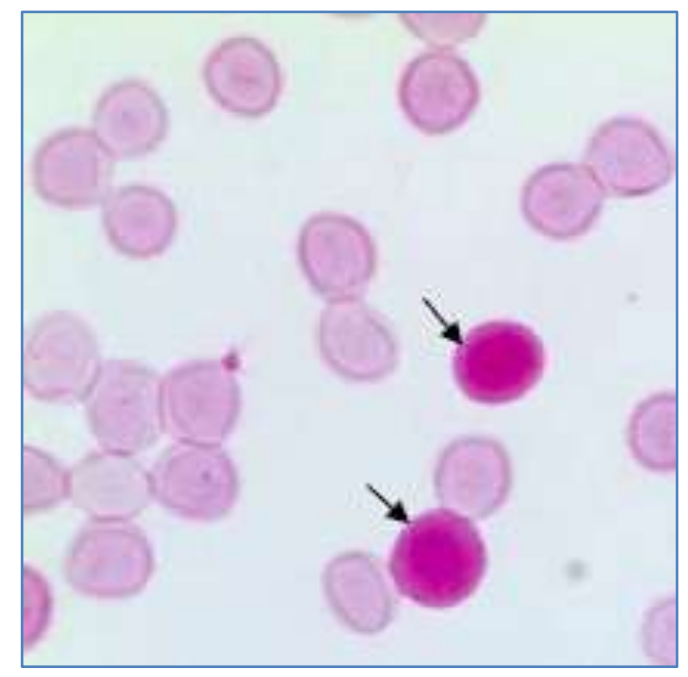

Fig-2: Red cells with HbF and surrounding red cells with adult haemoglobin

Table-2: Mode of delivery observed among 215 mothers during the study period

\begin{tabular}{|c|c|c|c|}
\hline Mode of delivery & No. of mothers & \% & \% of fetomaternal haemorrhage observed \\
\hline Normal delivery & 78 & 36.3 & 11 \\
\hline Assisted delivery & 31 & 14.4 & 46 \\
\hline LSCS & 106 & 49.3 & 43 \\
\hline
\end{tabular}

The proportion of mode of delivery and percentage of fetomaternal hemorrhage were also compared during the study period. 106 mothers (49.3\%) have undergone lower segment cesarean section, 78 mothers $(36.3 \%)$ had normal delivery and 31 mothers (14.4\%) had assisted delivery. Among that $46 \%$ of fetomaternal hemorrhage was observed in assisted mode of delivery, $43 \%$ of fetomaternal hemorrhage observed in mothers who underwent lower segmental cesarean sections and $11 \%$ of fetomaternal hemorrhage in mothers who had normal delivery [Table-2]. Thus the fetomaternal hemorrhage was lowest in normal deliveries in our study. 
Table- 3: Rh typing blood group distribution noted among 215 mothers and their neonates.

\begin{tabular}{|c|c|c|c|}
\hline Rh blood group of mother & Rh blood group of baby & No. of mothers & \% \\
\hline+ & - & 43 & 20.0 \\
\hline- & + & 66 & 30.7 \\
\hline- & - & 57 & 26.6 \\
\hline+ & + & 49 & 22.7 \\
\hline
\end{tabular}

Table-4: Application of Von Kleihauer Betke test in calculating the dose of RhIG required in Rh negative mothers with $\mathrm{Rh}$ positive babies

\begin{tabular}{|c|c|c|c|c|}
\hline $\begin{array}{c}\text { No. of mothers } \\
(\mathbf{6 6})\end{array}$ & $\begin{array}{c}\text { Fetal red } \\
\text { cells \% }\end{array}$ & $\begin{array}{c}\text { Fetomatermal haemorrhage (m) } \\
\text { [Fetal red cells \% x 50] }\end{array}$ & $\begin{array}{c}\text { No. of RhIG } \\
\text { vials calculated }\end{array}$ & $\begin{array}{c}\text { No. of vials of } \\
\text { RhIG given }\end{array}$ \\
\hline 3 & 0.0 & 0 & 0 & 1 \\
\hline 4 & 0.1 & 5 & 0.2 & 1 \\
\hline 2 & 0.2 & 10 & 0.3 & 1 \\
\hline 3 & 0.3 & 15 & 0.5 & 2 \\
\hline 3 & 0.4 & 20 & 0.6 & 2 \\
\hline 3 & 0.5 & 25 & 1.0 & - \\
\hline- & 0.6 & 30 & 1.2 & 2 \\
\hline 4 & 0.7 & 35 & 1.3 & 2 \\
\hline 7 & 0.8 & 40 & 1.5 & 3 \\
\hline 5 & 0.9 & 45 & 1.7 & 3 \\
\hline 6 & 1.0 & 50 & 2.8 & 3 \\
\hline 7 & 1.1 & 55 & 2.2 & 3 \\
\hline 8 & 1.2 & 60 & 2.3 & 3 \\
\hline 2 & 1.3 & 65 & 2.5 & - \\
\hline 1 & 1.4 & 70 & 2.7 & \\
\hline- & 1.5 & 75 & 2.8 & \\
\hline- & 1.6 & 80 & 3.0 & 4 \\
\hline 3 & 1.7 & 85 & 3.2 & 4 \\
\hline 3 & 1.8 & 90 & 3.3 & 4 \\
\hline 2 & 1.9 & 95 & & - \\
\hline- & 2.0 & 100 & & \\
\hline
\end{tabular}

$\mathrm{Rh}$ group of mothers and their neonates was also done and included in our study to calculate the dosage of RhIG to be given for the mothers in their postpartum period. Among 215 mothers, 66 (30.7\%) were found to be Rh negative and their corresponding neonates were $\mathrm{Rh}$ positive [Table-3]. For all the $\mathrm{Rh}$ negative mothers with their $\mathrm{Rh}$ positive neonate, the dosage of RhIG was calculated according to the percentage of fetal red cells in the maternal blood by applying Von Kleihauer Betke test. 12 mothers were given single dose of RhIG, 2 doses of RhIG were given in 22 mothers, 3 doses of RhIG were given in 24 mothers and 4 doses of RhIG were given in 8 mothers. (One single vial $=300 \mu \mathrm{g}$ RhIG) [22] [Table-4].

\section{DISCUSSION}

\section{Von Kleihauer Betke test}

\section{Reagents and Equipment}

Fetal cell fixing solution is Ethyl alcohol-80\%, buffer solution is Citric acid-phosphate buffer, $\mathrm{pH} 3.2$ to 3.3. Waterbath/ incubator with $37^{\circ} \mathrm{C}$ temperature. The stains used for fetal red cells detection are Erythrosin B (eosin B) stain, 0.1\% and Ehrlich's acid hematoxylin [10-13].

\section{Specimen required}

Make blood smears from venous blood collected in EDTA anticoagulant or from the fingertip. For best results blood should be less than 6 hours old, although successful staining has been achieve on specimens refrigerated for up to 2 weeks. The smears should be fixed within 2 hours of preparation.

\section{Principle}

Blood smears are fixed with ethyl alcohol and then incubated in a citric acid-buffer solution in an acid medium ( $\mathrm{pH} 3.2$ to 3.3), hemoglobin $\mathrm{F}$ is resistant to elution from the red blood cell, while other types are removed from the red cells. The slides are stained with hematoxylin (stains the white cell nuclei) and erythrosin B (stains the red cells). The smears are then reviewed microscopically to determine the presence of hemoglobin $\mathrm{F}$, and percentage of red blood cells containing fetal hemoglobin assessed [14-16].

\section{Procedure}

1. Prewarm citric acid-phosphate buffer and place 50 $\mathrm{ml}$ of the buffer solution into a coplin jar and cover. Incubate at $37^{\circ} \mathrm{C}$ for 30 minutes.

2. Preparation of thin blood smears. 
3. Allow the blood smears to air-dry for at least 10 minutes .

4. Fix blood smears (patient and controls) in $80 \%$ ethyl alcohol for 5 minutes

5. Rinse the smears carefully in distilled water and allow to air-dry .

6. Place the dry smears in the prewarmed citric acidphosphate buffer solution for 5 minutes. At 1 and 3 minutes of incubation, carefully lift each slide out of the buffer solution and immediately replace.

7. After 5 minutes, remove the slides from the citric acid-phosphate buffer solution and carefully rinse with distilled water and air-dry.the smears
8. Stain the dry smears in acid hematoxylin for 3 minutes. Rinse with distilled water and remove as much of the water as possible from the smears by gently tapping one end of the slide on an absorbent material .

9. Counterstain the smears with erythrosin B for 4 minutes. Rinse with distilled water, allow to airdry, and coverslip.

10. Examine the slides microscopically under oil immersion $100 \mathrm{x}$ objectives [17-19].

The percentage of fetal cells is delineated from a specially prepared slide containing the maternal blood sample. The calculation of percentage of fetal cells as:

Fetal red blood cells $\%=$

No. of fetal red cells counted

Total number of red blood cells counted

Normally, fetal cells should be absent in the maternal blood. The normal range is 0 to $0.1 \%$ as reported by the other laboratory references [20].

With the help of $\mathrm{HbF}$ percentage estimation number of RhIG vials needed for mothers can also be calculated. One vial of $\mathrm{RhIG}=300 \mu \mathrm{g}$ which will protect against $30 \mathrm{ml}$ of $\mathrm{Rh}$ positive fetal blood. The conversion factor used to indicate the volume of fetomaternal hemorrhage in millilitre of whole blood is, Fetal red cells percentage x 50 .

The calculation for RhIG vials required is,

No. of RhIG vials required $=$ Fetal red cells percentage $\mathrm{X} 50 / 30$.

When the number to the right of the decimal point is greater than 5, round up and add one dose. When the number to the right of the decimal point is less than 5, round down and add one dose [21]. Our study is comparable with other previous studies of Davis et al., Pora, et al. and De Wit et al. [2, $4,5]$.

\section{SUMMARY \& CONCLUSION}

The Von Kleihauer betke acid elution test was applied in calculating labor induced fetomaternal haemorrhage and the observed value was less than $2 \%$ in the study group, implying low significance.

The Von Kleihauer betke acid elution test has several major advantages as it is a simple and easy way to implement the method. It requires only usual laboratory hardware and it does not involve large costs, and as such it is affordable for any type of laboratory. Disadvantages of Von Kleihauer Betke test is that it is only semi-quantitative, although this is only a significant objection when calculating RhIG dose, an indication for which the major imperative is to avoid under-dosing with RhIG. In practice, the major disadvantages of the Von Kleihauer Betke test are the subjective nature of the interpretation and the inherent variability of the test based on staining quality. Both over- and underestimation of fetomaternal hemorrhage have been reported, but most studies report a tendency of the Von Kleihauer Betke test test to overestimate fetomaternal hemorrhage. If mother and fetus are ABO incompatible, the fetal cells may disappear from the mother's circulation quickly, and an underestimate of fetomaternal haemorrhage will be made. Incomplete staining of fetal cells in the Von Kleihauer Betke test can also contribute to underestimation [23].

In order to reduce the over and under estimation of $\mathrm{HbF}$ in fetomaternal hemorrhage, CAP proficiency surveys proposed that flow cytometry method using anti-HbF antibodies is more precise than the Von Kleihauer betke acid elution test and are more accurate. Flow cytometry using monoclonal antibodies to $\mathrm{HbF}$ represents the detection of fetomaternal hemorrhage when quantitative accuracy is important. In published literature reports, flow cytometry is more objective, quantitative, reproducible, sensitive, and specific than the Von Kleihauer betke acid elution test method. As a side benefit, the percentage of F-cells in the mother can be directly quantitated and may correlate with clinical conditions in which the $\mathrm{Hb} \mathrm{F}$ level is raised. The Flow cytometry method utilizes monoclonal antibodies to $\mathrm{HbF}$ incubated with permeabilized suspensions of red cells in whole blood to achieve intracellular staining. The fluorescence intensity of 50,000 red cells stained with fluorochrometagged anti-HbF monoclonal antibody can be obtained in the cytometer in a few minutes. The intensity of fluorescence of each stained red cell is proportional to the concentration of $\mathrm{HbF}$ [24].

\section{Future Scope}

Von Kleihauer betke acid elution test can also be used a] in newborn to assess maternal erythrocytes in fetal circulation, b] in the newborn who develops an unexpected anemia or intrauterine death, c] in cord 
blood harvested through cordocentesis or from the amniotic fluid, for monitoring the clearance of fetal RhD positive red cells in fetomaternal hemorrhage following RhIG administration along with flow cytometry assay. Further studies can be made by applying this simple acid elution test assay in newborns to assess $\mathrm{HbF}$ percentage to rule out any congenital hemoglobinopathies as well.

\section{ACKNOWLEDGEMENTS}

The authors are thankful to the Chairman, the Dean and the Medical superintendent, Institutional scientific and ethical committee for the approval to conduct the study.

\section{Ethical Approval}

This study was approved by the Institutional Ethics Committee

\section{REFERENCES}

1. Sebring, E. S., \& Polesky, H. F. (1990). Fetomaternal hemorrhage: incidence, risk factors, time of occurrence, and clinical effects. Transfusion, 30(4), 344-357.

2. De, Wit. (2011). American Journal of Clinical Pathology, 136: 631-636.

3. Kim, Y.A., Makar, R.S. (2012). Am J Hematol, 87(4); 417-23

4. Chen, J.C., Davis, B.H. (1998). Cytometry, 50(6), Dec 2002: 285-290

5. Pora, V., Bernauet, J. (2007). Transfusion Vol 47, Issue 7, July 2007: 1281-1289

6. Sandler, G.S., Gottschall, J.L. (2012). Obstet Gynecol, 120:1428-1438

7. Avent, N.D., \& Reid, M.E. (2000). Blood, 95:375387

8. Chou, M.W., Westhoff, C.M. (2009). Hematology American Society of Hematology: 178-184

9. Connie, M. (2008). Wethoff, PhD, MT (ASCP) SBB. Technical Manual. Bethesda: AABB.

10. W.J. Judd, M. M. (2005). Immunohematology, 146-148.

11. Willy, A., Flegel, M. G. (2007). J Obstet Gynaecology, Canada, 746-752.

12. Kleihauer, E., Braun, H., \& Betke, K. (1957). Demonstration von fetalem hemoglobin in den erythrozyten eines blu tausstriches. Klin Wochenschr, 35, 637-638.
13. Howarth, D. J., Robinson, F. M., Williams, M., \& Norfolk, D. R. (2002). A modified Kleihauer technique for the quantification of foetomaternal haemorrhage. Transfusion Medicine, 12(6), 373 378.

14. Kelsey, P., Reilly, B.C.S.H. (1999). Guidelines for the estimation of fetomaternal haemorrhage, Transfusion Medicine, 9: 87-92.

15. Quinley, E.D. (1993). Immunohematology Principles and Practice, ed. I.B. Lippincott, 276308.

16. Widmann, F.K. (1985). Technical Manual, 9th Edition Arlington, American Association of Blood Banks, 179-191.

17. Woodfield, G., Davis, K., Francis, A. (2002). Guidelines for laboratory assessment of fetomaternal haemorrhage, 1st ed.Sidney: ANZBT.

18. Mollison, P.L., Engelfriet, C.P., Contreras, M. (2005). Blood Transfusion in clinical medicine, 11 Ed, 498- 545.

19. Conte, R., Tassi, C., Malferrari, F., Giannotti, G. A., Barbieri, P., Donzelli, C., \& Londero, D. (1999). Valutazione comparativa fra ID-FMH DiaMed e il test di eluizione acida di KleihauerBetke. Studio multicentrico. Trasfusione del Sangue, 44(3), 141-146.

20. Leonova, J. Y., Kazanetz, E. G., Smetanina, N. S., Adekile, A. D., Efremov, G. D., \& Huisman, T. H. (1996). Variability in the fetal hemoglobin level of the normal adult. American journal of hematology, 53(2), 59-65.

21. Patton, W. N., Nicholson, G. S., Sawers, A. H., Franklin, I. M., Ala, F. A., \& Simpson, A. W. (1990). Assessment of fetal-maternal haemorrhage in mothers with hereditary persistence of fetal haemoglobin. Journal of clinical pathology, 43(9), 728-731.

22. Simonnet, C., \& Brossard, Y. (2001). Standardisation du test de Kleihauer. In Annales de biologie Clinique, 59(6), 768-0.

23. Salim, R., Ben-Shlomo, I., Nachum, Z., Mader, R., \& Shalev, E. (2005). The incidence of large fetomaternal hemorrhage and the Kleihauer-Betke test. Obstetrics \& Gynecology, 105(5), 1039-1044.

24. Lubenko, A., Williams, M., Johnson, A., Pluck, J., Armstrong, D., \& MacLennan, S. (1999). Monitoring the clearance of fetal RhD-positive red cells in $\mathrm{FMH}$ following $\mathrm{RhD}$ immunoglobulin administration. Transfusion Medicine, 9(4), 331335. 